\title{
A meta-analysis of the association of the ACE I/D and PAI-1 4G/5G polymorphisms with recurrent pregnancy loss in Iranian women: Are the investigations adequate?
}

İranlı kadınlarda tekrarlayan gebelik kaybı ile ACE I/D ve PAI-1 4G/5G polimorfizmlerinin ilişkisine yönelik bir meta-analiz: Arasstırmalar yeterli mi? \author{
(1) Atiyeh Javaheri ${ }^{5}$, (1) Mahmood Noorishadkam ${ }^{6}$, (1) Seyed Reza Mirjalili ${ }^{6}$, (1) Hossein Neamatzadeh 6,7 \\ ${ }_{1}^{1}$ Department of Medical Genetics, School of Medicine, Shiraz University of Medical Sciences, Shiraz, Iran \\ 2 Department of Obstetrics and Gynecology, Firoozgar Hospital, Iran University of Medical Sciences, Tehran, Iran \\ ${ }^{3}$ Endometriosis Research Center, Iran University of Medical Sciences, Tehran, Iran \\ ${ }^{4}$ Neonatal Research Center, Shiraz University of Medical Sciences, Shiraz, Iran \\ 5 Department of Obstetrics and Gynecology, Shahid Sadoughi University of Medical Sciences, Yazd, Iran \\ 6Mother and Newborn Health Research Center, Shahid Sadoughi University of Medical Sciences, Yazd, Iran \\ 7Department of Medical Genetics, Shahid Sadoughi University of Medical Sciences, Yazd, Iran
}

(1) Seyed Alireza Dastgheib ${ }^{1}$, (1) Mojgan Karimi-Zarchi²,3, (1) Reza Bahrami ${ }^{4}$, (1) Razieh Sadat Tabatabaei ${ }^{5}$,

\begin{abstract}
The associations of ACE I/D and PAI-1 4G/5G polymorphisms with recurrent pregnancy loss (RPL) in Iranian women have yielded controversial results. Thus, we conducted a meta-analysis to obtain more certain results. A comprehensive literature search was performed in the PubMed, Web of Sciences, Scopus, MedRxiv, SID, and CNKI databases up to January $1^{\text {st }}$, 2021, using the appropriate terms. All case-control studies were included. Odds ratios (ORs) and $95 \%$ confidence intervals (CIs) were used to estimate the strength of associations. A total of 14 studies including eight studies with 783 patients and 761 healthy subjects on ACE I/D and six studies with 1.155 patients and 699 healthy subjects on PAI-1 4G/5G were included. Combined data revealed that ACE I/D polymorphism was significantly associated with RPL risk in Iranian women under three models i.e., allele [OR=0.744, 95\% CI: (0.640-0.864); $\mathrm{p} \leq 0.001$ ], dominant [OR=0.774, 95\% CI: (0.601-0.996); $\mathrm{p}=0.047$ ], and recessive [OR=0.767, 95\% CI: (0.611-0.963); $\mathrm{p}=0.022]$. Moreover, the pooled data showed a significant association between the PAI-1 4G/5G polymorphism and RPL risk under all five models i.e., allele [OR=2.352, 95\% CI: (1.623-3.408); $\mathrm{p} \leq 0.001$ ], heterozygote [OR=8.364, 95\% CI: (4.744-14.756); $\mathrm{p} \leq 0.001)$, homozygote [OR=2.192, 95\% CI: (1.093-4.394); $\mathrm{p}=0.027)$, dominant [OR=2.354, 95\% CI: (1.309-4.235); $\mathrm{p}=0.004]$, and recessive [OR=5.208, 95\% CI: (3.005-9.025); $\leq 0.001]$. Stratification analysis revealed that these polymorphisms were associated with RPL risk by the number of miscarriages. Our pooled data indicated that ACE I/D and PAI-1 4G/5G polymorphisms were significantly associated with an increased risk of RPL in Iranian women. These significant findings showed that the investigation might be adequate for ACE I/D and PAI-1 4G/5G polymorphisms in the Iranian population.
\end{abstract}

Keywords: Pregnancy loss, miscarriage, thrombophilia, plasminogen activator inhibitor-1, angiotensin-I-converting enzyme, polymorphism

$\ddot{\mathrm{O} z}$

İranlı kadınlarda ACE I/D ve PAI-1 4G/5G polimorfizmlerinin tekrarlayan gebelik kaybı (TGK) ile ilişkisi tartışmalı sonuçlar vermiştir. Bu yüzden, daha güvenilir sonuçlar almak için bir meta-analiz gerçekleştirdik. PubMed, Web of Sciences, Scopus, MedRxiv, SID ve CNKI veritabanlarında uygun terimler kullanılarak 01 Ocak 2021 tarihine kadar kapsamlı bir literatür taraması gerçekleștirildi. Tüm olgu kontrol çalışmaları dahil edildi. İlişkilerin gücünü tahmin etmek için olasılık oranları (OO'lar) ve \%95 güven aralıkları (GA) kullanıldı. Meta-analize ACE I/D ile ilgili 783 hasta ve 761 sağlıklı denek içeren 8 çalışma ve PAI-1 4G/5G ile ilgili 1.155 hasta ve 699 sağlıklı denek içeren 6 çalışma dahil olmak üzere toplam 14 çalışma dahil edildi. Birleşik veriler, ACE I/D polimorfizminin; allel $(\mathrm{OO}=0,744, \% 95$ GA: 0,640-0,864, $\mathrm{p} \leq 0,001)$, dominant $(\mathrm{OO}=0,774, \% 95$ GA: 0,601-0,996, $\mathrm{p}=0,047)$ ve resesif $(\mathrm{OO}=0,767$, \%95 GA: 0,611-0,963, p=0,022) olmak üzere üç model altında İranlı kadınlarda TGK riski ile önemli ölçüde ilişkili olduğunu ortaya koymuştur. Ayrıca,

Address for Correspondence/Yazışma Adresi: Asst. Prof. Reza Bahrami,

Department of Obstetrics and Gynecology, Firoozgar Hospital, Iran University of Medical Sciences, Tehran, Iran

Phone: +00989215737221 E-mail: r.bahrami.neo@gmail.com ORCID ID: orcid.org/0000-0002-8554-4562

Received/Geliș Tarihi: 16.09.2020 Accepted/Kabul Tarihi: 07.04.2021

${ }^{\circledR}$ Copyright 2021 by Turkish Society of Obstetrics and Gynecology

Turkish Journal of Obstetrics and Gynecology published by Galenos Publishing House. 
havuzlanmış veriler, PAI-1 4G/5G polimorfizmi ile TGK riski arasında, beş modelin tümünde, yani allel (OO=2,352, \%95 GA: 1,623-3,408, p $\leq 0,001)$, heterozigot (OO=8,364, \%95 GA: 4,744-14,756, p $\leq 0,001)$, homozigot (OO=2,192, \%95 GA: 1,093-4,394, p=0,027), dominant (OO=2,354, \%95

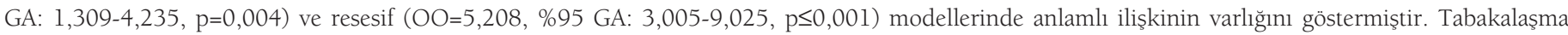
analizi, bu polimorfizmlerin düşük sayısına göre TGK riski ile ilişkili olduğunu ortaya çıkarmıştır. Birleştirilmiş verilerimiz, ACE I/D ve PAI-1 4G/5G polimorfizmlerinin, İranlı kadınlarda artmış TGK riski ile önemli ölçüde ilişkili olduğunu gösterdi. Bu önemli bulgular bizi, İran popülasyonunda ACE I/D ve PAI-1 4G/5G polimorfizmleri açısından araştırmanın yeterli olabileceği kararına götürdü.

Anahtar Kelimeler: Gebelik kaybı, düşük, trombofili, plazminojen aktivatör inhibitörü-1, anjiyotensin-I-dönüştürücü enzim, polimorfizm

\section{Introduction}

Recurrent pregnancy loss (RPL) is one of the main public health issues with a rate of $5 \%$ among women of reproductive age $^{(1,2)}$. RPL is defined as the loss of three or more successive pregnancies before viability and includes all pregnancy losses from the time of conception until 24 weeks of gestation ${ }^{(3-5)}$. The most commonly cited causes of miscarriage are structural chromosome abnormalities of one of the partners, uterine abnormalities, elevated random levels of homocysteine, and antiphospholipid syndrome ${ }^{(6,7)}$. Thrombophilia is described as a susceptibility to arterial or venous thrombotic complications due to hemostatic system defects, which may be acquired, like the antiphospholipid syndrome, or inherited ${ }^{(8,9)}$. Adverse pregnancy outcomes, such as pregnancy failure (i.e. sporadic and RPL, late fetal loss), pre-eclampsia, and HELLP syndrome, are associated with thrombotic mechanisms and thrombophilia ${ }^{(10)}$. Thrombotic disorders are detectable in $40-50 \%$ of RPL cases ${ }^{(11)}$. It has been presumed that the etiology of RPL is associated with factors involved in fibrinolysis and coagulation ${ }^{(3,12)}$. In the past two decades, several investigators suggested that thrombophilia had an impact on susceptibility to RPL ${ }^{(13-15)}$. Thus, genotyping of genetic variants at thrombophilic genes is useful to describe the etiology of RPL, and improvement our knowledge about the nature of this disease ${ }^{(16)}$.

Currently, there are a limited number of genetic variants as independent risk factors for venous thromboembolism in women with RPL ${ }^{(17)}$. There is growing evidence of a causal relationship of genetic variations at plasminogen activator inhibitor-1 (PAI-1) and angiotensin-converting enzyme (ACE) genes with RPL in different populations ${ }^{(3,18)}$. PAI-1, a $52 \mathrm{kDa}$ glycoprotein belonging to the serine proteinase inhibitor superfamily, is the principal inhibitor of tissue and urinary plasminogen activators ${ }^{(3,19,20)}$. PAI-1 is involved in various physiologic functions and associated with many diseases ${ }^{(21-23)}$. The most commonly studied functional variant in the PAI-1 gene is the $4 \mathrm{G} / 5 \mathrm{G}$ polymorphism, which is characterized by a single guanosine nucleotide insertion/deletion variation at $-675 \mathrm{bp}$ to the transcription start site of the PAI-1 gene $\mathrm{g}^{(24,25)}$. Moreover, ACE or kininase II, is a dipeptidyl carboxypeptidase that plays an important role in regulating blood pressure and electrolyte balance ${ }^{(26,27)}$. The most widely studied polymorphism of ACE is an insertion/deletion (I/D), which is characterized by insertion or deletion of a 287-non-coding base pair Alu repeat sequence $e^{(28,29)}$.
RPL is one of the main reproductive health issues in $\operatorname{Iran}{ }^{(30,31)}$. However, there is no consensus regarding the frequency of RPL in Iranian women. In the past decade, several molecular studies have evaluated the association of ACE I/D and PAI-1 4G/5G polymorphisms with RPL risk in $\operatorname{Iran}^{(3,18)}$. Nevertheless, their results were inconsistent and inconclusive. Moreover, the findings provided limited evidence due to relatively small sample sizes and might have been underpowered to estimate the risk. Thus, meta-analysis is a standardized approach to combine the results of different studies on ACE I/D and PAI-1 $4 G / 5 G$ polymorphisms to provide more reliable conclusions. Therefore, we conducted this meta-analysis to obtain a more precise estimation on the association of ACE I/D and PAI-1 4G/5G polymorphisms with RPL risk in Iranian women from all eligible case-control studies published in English and Farsi.

\section{Materials and Methods}

\section{Search Strategy}

We performed a comprehensive search on the United States National Library of Medicine's PubMed, Scopus, EMBASE, Web of Knowledge, MedRxiv, Cochrane Library, Google Scholar, Scientific Information Database, WanFang, VIP, Chinese Biomedical Database, Scientific Electronic Library Online and China National Knowledge Infrastructure database to find all relevant publications on the association of ACE I/D and PAI-1 4G/5G polymorphisms with RPL in Iranian women up till January $1^{\text {st }}, 2021$. The following keywords and terms were used for the search: ("Pregnancy Loss" OR "RPL" OR "Recurrent Pregnancy Loss" OR "Recurrent Miscarriage" OR "recurrent spontaneous abortion" OR "Idiopathic/Unexplained Recurrent Pregnancy Loss") AND ("Angiotensin-Converting Enzyme" OR "ACE" OR "SERPINEl") AND ("Insertion/Deletion Polymorphism" OR "ACE I/D" OR "rs4646994") AND ("Plasminogen Activator Inhibitor-1" OR "PAI-1") AND ("4G/5G" OR "rs1799889") AND ("Gene" OR "Genotype" OR "Allele" OR "Polymorphism" OR "Single nucleotide polymorphisms" OR "SNP" OR "Variation" OR "Mutation"). Articles were limited to the English and Farsi languages. Additionally, the reference lists of each eligible study, previous meta-analyses, and review articles were manually checked to find more relevant publications.

\section{Inclusion and Exclusion Criteria}

The criteria employed to retrieve publications for this metaanalysis were as follows: (1) studies with case-control or cohort design; (2) studies conducted among Iranian populations; (3) 
studies that evaluated the association of ACE I/D and PAI-1 4G/5G polymorphisms with RPL; (4) studies that provided sufficient data on the genotype frequencies of the polymorphisms to calculate the pooled odds ratio (OR) with corresponding 95\% confidence interval (CI). The exclusion criteria were as follows: (1) studies not relevant to RPL; (2) case-only studies or no controls; (3) linkage studies and family-based studies (twins and sibling); (4) duplicate studies and incomplete data; (5) abstracts, posters, presentations, letters, case reports, case series, comments, conference editorials, reviews and previous meta-analyses; and (6) unpublished data and studies without extractable data.

\section{Data Extraction}

Data were carefully extracted from all eligible studies independently by two authors according to the criteria listed above. Then, to minimize bias and to improve the reliability of the data, the authors checked all potentially relevant studies independently and reached a consensus or a third author was consulted to make a final decision. The following data were collected from each study: name of the first author, year of publication, genotyping method, numbers of patients with RPL and healthy controls, genotypes and alleles frequencies in patients and controls for ACE I/D and PAI- 1 GG/5G polymorphisms, minor allele frequency, and p-values for Hardy-Weinberg equilibrium (HWE) tests in control subjects. If a study included more than one case-control group, each studied group was considered as an independent dataset. For studies with overlapping data or samples by the same author, the larger sample size or the study that was published more recently was included in the meta-analysis.

\section{Statistical Analysis}

The strength of the association between ACE I/D and PAI-1 4G/5G polymorphisms and RPL risk in Iranian women was calculated using odds ratios (ORs) with 95\% confidence intervals (CIs). The significance of the pooled OR was determined using the Z-test, in which a p-value $<0.05$ was considered significant. The pooled ORs for ACE I/D and PAI-1 4G/5G polymorphisms were estimated under all five genetic comparison models, i.e., allele (A vs B), homozygote (AA vs BB), heterozygote (BA vs $B B)$, dominant $(A A+B A v s B B)$, and recessive ( $A A$ vs $B A+B B)$. A Cochrane-based $Q$ statistical test was used to test betweenstudies heterogeneity, in which p-values $<0.1$ indicated the absence of indicated heterogeneity. Moreover, we used the inconsistency index $\left(\mathrm{I}^{2}\right.$ ) (range of 0 to $100 \%$ ) to quantify the proportion of the total variation due to heterogeneity, in which the heterogeneity was considered low, moderate, and high based on $\mathrm{I}^{2}$ values of $25 \%, 50 \%$, and $75 \%$, respectively. If heterogeneity was observed among the studies, the randomeffects model (the DerSimonian and Laird method) was used to estimate the pooled OR. Otherwise, a fixed-effects model (the Mantel-Haenszel method) was adopted. For each study, the HWE in healthy subjects was estimated using the chi-square goodness-of-fit test and $\mathrm{p}<0.05$ was considered statistically significant. Sensitivity analysis was performed by sequential omission of individual studies to assess the stability of pooled data in this meta-analysis. Moreover, sensitivity analysis was performed by excluding studies that deviated from the HWE. Both Begg's funnel plot and Egger's weighted regression tests were used to assess publication bias. If publication bias existed, the Duval and Tweedie non-parametric "trim and fill" method was applied to adjust results. All statistical analyses were performed using the Comprehensive Meta-analysis (CMA) software version 2.0 (Biostat, USA). Two-sided probability (p) values of $<0.05$ were considered statistically significant.

\section{Results}

\section{Study Selection and Characteristics}

A flow chart detailing the inclusion/exclusion process is shown in Figure 1. The primary online database queries and manual reference searches generated 337 potentially relevant studies that reported the association of ACE I/D and PAI-1 4G/5G polymorphisms with susceptibility to RPL. After the removal of duplicate articles, the search retrieved 218 items. Based on the title, abstract screening, or both, 129 articles were excluded according to the eligibility criteria. Subsequently, 75 publications were excluded because they were reviews, previous meta-analyses, and evaluated the association of RPL with other polymorphism of ACE and PAI-1 genes. Finally, a total of 14 studies involving eight studies with 783 patients and 761 controls on the ACE I/D polymorphism ${ }^{(6,18,29,32-35)}$ and six studies with 1155 patients and 699 controls on the PAI-1 4G/5G polymorphism ${ }^{(18,31,34,36-38)}$ were included in this meta-analysis. One study in the present meta-analysis did not state the source of controls. Two genotyping methods were used, including ARMS-PCR and PCR-RFLP. The genotype distributions among the controls in the two studies were not consistent with the HWE on the ACE I/D polymorphism (Table 1).

\section{Quantitative Data Synthesis}

\section{ACE I/D Polymorphism}

The pooled results on the association of ACE I/D polymorphism with RPL risk in Iranian women are presented in Table 2. When all eligible studies were pooled together, a significant association between ACE I/D polymorphism and increased risk of RPL in Iranian women was found only under three models i.e., allele [D vs I: OR=0.744, 95\% CI: (0.640-0.864); $\mathrm{p} \leq 0.001$, Figure $2 \mathrm{~A}]$, dominant [DD+DI vs II: $\mathrm{OR}=0.774,95 \%$ CI: (0.601-0.996); $\mathrm{p}=0.047$, Figure $2 \mathrm{~B}$ ], and recessive [DD vs DI+II: OR=0.767, 95\% CI: (0.611-0.963); $\mathrm{p}=0.022$, Figure 2C]. When stratified by the number of recurrent miscarriages (RM), a significant association between the ACE I/D polymorphism and increased risk of RPL was detected in the group of studies with $\geq 2$ RMs under the allele genetic model [D vs I: $O R=0.666,95 \%$ CI: (0.539-0.822); $\mathrm{p} \leq 0.001]$, but not in studies with $\geq 3 \mathrm{RM}$. 


\section{PRISMA 2009 Flow Diagram}

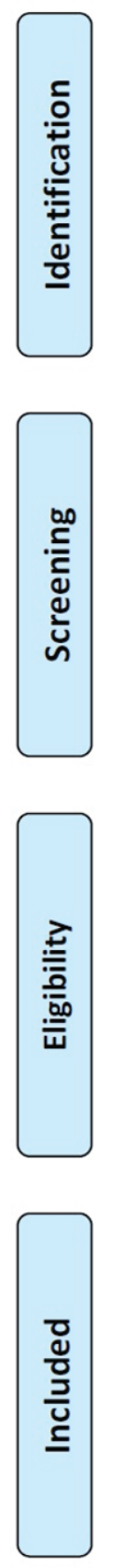

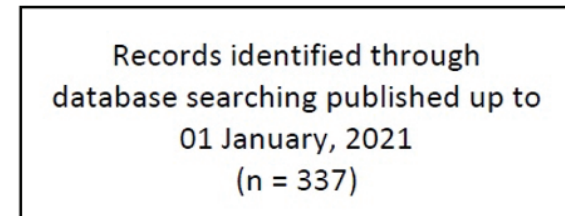

$(n=337)$
Additional records identified

through other sources published up

to 01 January, 2021

$(n=1)$

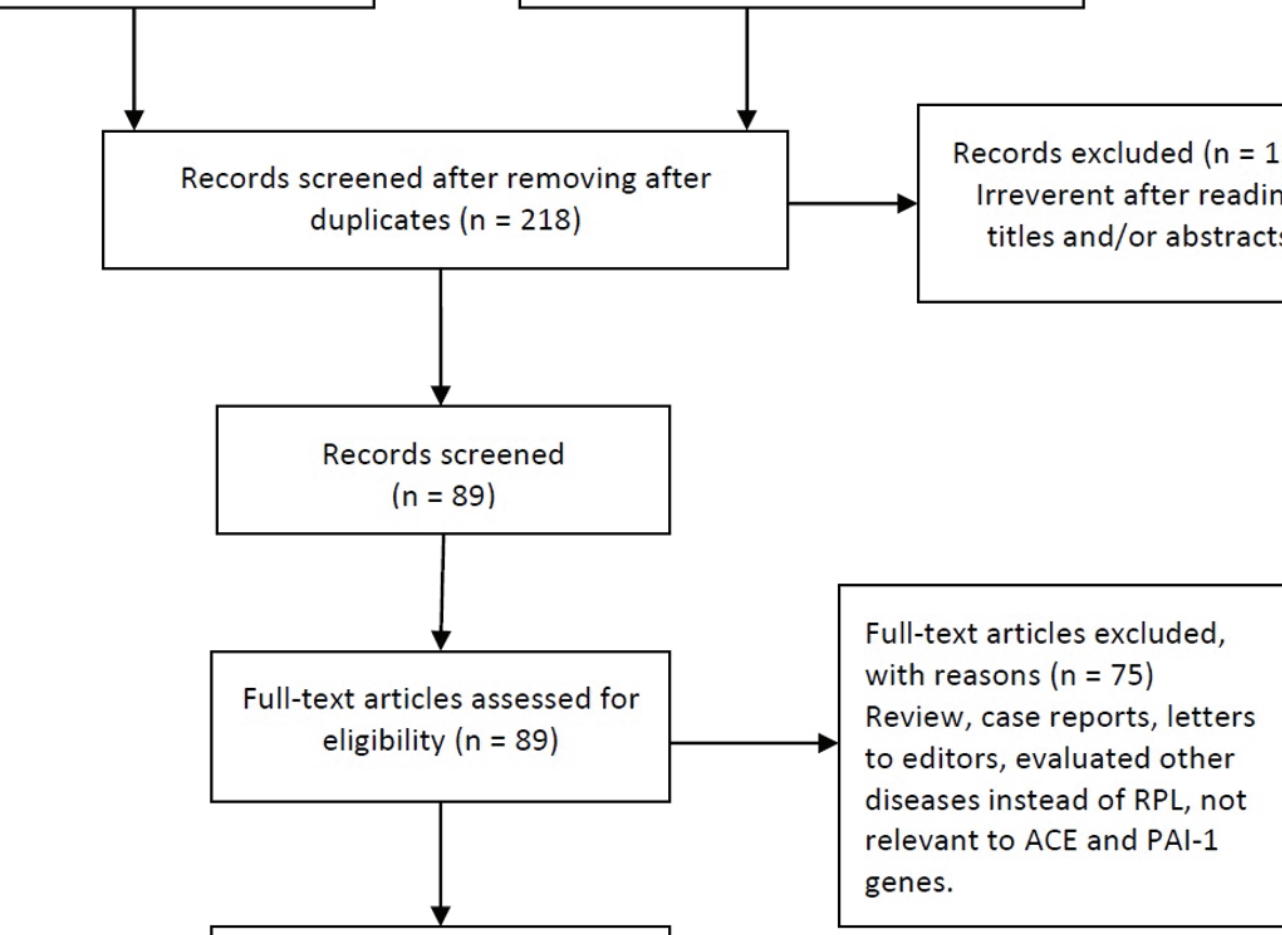

Studies included in

qualitative synthesis

( $n=14)$

Studies included in quantitative synthesis

( $n=14$ case-control studies)

ACE I/D: 8 studies with 783 cases and 761 healthy subjects

PAI-1 4G/5G: 6 studies with 1,155 cases and 699 controls

Figure 1. Flow diagram of selection of studies included in the meta-analysis

Moreover, a significant association was found between ACE I/D and RPL in ARMS-PCR group studies under two genetic models i.e., allele [D vs I: $\mathrm{OR}=0.799,95 \% \mathrm{CI}$ : $(0.659-0.967) ; \mathrm{p}=0.022$ ] and recessive [DD vs DI+II: OR=0.734, 95\% CI: (0.544-0.989); $\mathrm{p}=0.042]$, and PCR-RFLP group studies under the allele model [D vs I: OR=0.667, 95\% CI: (0.524-0.850); $\mathrm{p}=0.001)$.
PAI-1 4G/5G Polymorphism

Table 3 summarizes the main results of the meta-analysis for the PAI-1 4G/5G polymorphism and RPL in Iranian women. Overall pooled data showed that there was a significant association between the PAI-1 4G/5G polymorphism with 
Table 1. Main characteristics of studies included in this meta-analysis

\begin{tabular}{|c|c|c|c|c|c|c|c|c|c|c|c|c|c|c|c|}
\hline \multirow{3}{*}{$\begin{array}{l}\text { First author } \\
\text { ACE I/D }\end{array}$} & \multirow{3}{*}{$\begin{array}{l}\text { Genotyping } \\
\text { technique }\end{array}$} & \multirow{3}{*}{$\begin{array}{l}\text { RM } \\
\text { NO. }\end{array}$} & \multirow{3}{*}{$\begin{array}{l}\text { Case/ } \\
\text { Control } \\
\end{array}$} & \multicolumn{5}{|l|}{ Cases } & \multicolumn{5}{|c|}{ Controls } & \multirow{3}{*}{ MAFs } & \multirow{3}{*}{ HWE } \\
\hline & & & & \multicolumn{3}{|c|}{ Genotype } & \multicolumn{2}{|c|}{ Allele } & \multicolumn{3}{|c|}{ Genotype } & \multicolumn{2}{|c|}{ Allele } & & \\
\hline & & & & II & ID & DD & I & $\mathrm{D}$ & II & ID & DD & I & D & & \\
\hline $\begin{array}{l}\text { Soltanghoraee } \\
\text { et al. }{ }^{(32)}\end{array}$ & PCR-RFLP & $\geq 2$ & $129 / 94$ & 29 & 62 & 38 & 112 & 128 & 22 & 47 & 25 & 108 & 116 & 0.484 & 0.992 \\
\hline Bagheri et al. ${ }^{(33)}$ & ARMS-PCR & $\geq 3$ & $50 / 63$ & 7 & 26 & 17 & 40 & 60 & 12 & 27 & 24 & 51 & 75 & 0.404 & 0.380 \\
\hline $\begin{array}{l}\text { Poursadegh } \\
\text { Zonouzi et al. }{ }^{(35)}\end{array}$ & ARMS-PCR & $\geq 2$ & $89 / 50$ & 35 & 31 & 23 & 101 & 77 & 15 & 28 & 7 & 58 & 42 & 0.580 & 0.135 \\
\hline $\begin{array}{l}\text { Shahkarami et } \\
\text { al. }{ }^{(18)}\end{array}$ & PCR-RFLP & $\geq 2$ & $100 / 100$ & 6 & 60 & 34 & 74 & 128 & 0 & 48 & 52 & 48 & 152 & 0.240 & 0.001 \\
\hline PAI-1 4G/5G & & & & $5 G 5 G$ & $5 G 4 G$ & $4 G 4 G$ & $5 G$ & $4 G$ & $5 G 5 G$ & $5 G 4 G$ & $4 G 4 G$ & $5 G$ & $4 G$ & & \\
\hline Arabi et al. ${ }^{(34)}$ & PCR-RFLP & $\geq 3$ & $54 / 99$ & 21 & 23 & 10 & 65 & 43 & 31 & 66 & 2 & 128 & 70 & $\leq 0.001$ & 0.354 \\
\hline $\begin{array}{l}\text { Jeddi-Tehran et } \\
\text { al. }{ }^{(36)}\end{array}$ & PCR-RFLP & $\geq 2$ & $100 / 100$ & 60 & 31 & 9 & 151 & 49 & 72 & 27 & 1 & 171 & 29 & 0.373 & 0.145 \\
\hline Idali et al. ${ }^{(37)}$ & PCR-RFLP & $\geq 3$ & $106 / 100$ & 35 & 53 & 18 & 123 & 89 & 72 & 27 & 1 & 171 & 29 & 0.373 & 0.145 \\
\hline $\begin{array}{l}\text { Khosravi et } \\
\text { al. }{ }^{(38)}\end{array}$ & PCR-RFLP & $\geq 2$ & $595 / 100$ & 128 & 208 & 85 & 464 & 375 & 72 & 27 & 1 & 171 & 29 & 0.373 & 0.145 \\
\hline $\begin{array}{l}\text { Shahkarami et } \\
\text { al. }{ }^{(18)}\end{array}$ & PCR-RFLP & $\geq 2$ & $100 / 100$ & 33 & 50 & 17 & 116 & 84 & 45 & 50 & 5 & 140 & 60 & 0.300 & 0.056 \\
\hline
\end{tabular}

PCR: Polymerase chain reaction, RFLP: Restriction fragment length polymorphism, RM: Recurrent miscarriage, MAF: Minor allele frequency, HWE: Hardy-Weinberg equilibrium

RPL risk under all five genetic models i.e., allele [4G4G vs 5G5G: OR=2.352, 95\% CI: (1.623-3.408); $\mathrm{p} \leq 0.001$, Figure $3 \mathrm{~A}$ ], heterozygote [4G4G4 vs 5G5G5: OR=8.364, 95\% CI: (4.744-14.756); $\mathrm{p} \leq 0.001$, Figure 3B], homozygote [4G5G vs 5G5G: OR=2.192, 95\% CI: (1.093-4.394); $\mathrm{p}=0.027$, Figure 3C], dominant [4G4G4+4G5G vs 5G5G5: OR=2.354, 95\% CI: (1.309-4.235); $p=0.004$, Figure 3D], and recessive [4G4G4 vs 4G5G+5G5G5: OR=5.208, 95\% CI: (3.005-9.025); $\mathrm{p} \leq 0.001$, Figure 3E]. When stratified by RM, a significant association between PAI-1 4G/5G polymorphism and increased risk of RPL was detected in the group of studies with $\geq 2$ RMs under four genetic models i.e., allele [4G4G vs 5G5G: $\mathrm{OR}=2.083$, 95\% CI: (1.617-2.682); p $\leq 0.001$ ], homozygote [4G5G vs 5G5G: $\mathrm{OR}=8.390,95 \% \mathrm{CI}:(3.509-20.061) ; \mathrm{p} \leq 0.001]$, dominant [4G4G4+4G5G vs 5G5G5: OR=2.003, 95\% CI: (1.472-2.727); $\mathrm{p} \leq 0.001$ ], and recessive [4G4G4 vs 4G5G+5G5G5: OR=5.871, 95\% CI: (2.528-13.631); $\leq \leq 0.001]$, and $\geq 3$ under three genetic models i.e., allele [4G4G vs 5G5G: OR=2.653, 95\% CI: (1.2995.418); $\mathrm{p}=0.007$ ], homozygote [4G5G vs 5G5G: $\mathrm{OR}=8.345$, 95\% CI: (3.955-17.606); $\mathrm{p} \leq 0.001$ ], and recessive [4G4G4 vs 4G5G+5G5G5: OR=4.764, 95\% CI: (2.305-9.845); $\leq 0.001]$.

\section{Heterogeneity Test and Sensitivity Analysis}

There was no between-study heterogeneity found in all five genetic models and thus the fixed-effect model was applied to calculate their combined OR. Moreover, we conducted a sensitivity analysis to investigate whether the absence of each study would alter the pooled ORs and stability of our results. However, we observed no significant change in the association level of ACE I/D and PAI-1 4G/5G polymorphisms with RPL risk in the Iranian population by excluding any of the studies. This suggests that that the current meta-analysis results were relatively robust and stable.

\section{Publication Bias}

The publication bias of the studies was assessed using a funnel plot and Egger's test (Table 2 and Figure 4A-B). The funnel plot did not indicate any evidence of funnel plot asymmetry for the ACE I/D polymorphism. Moreover, the results of Egger's test revealed no significant publication bias for the ACE I/D polymorphism. However, Begg's funnel plot and Egger's tests showed publication bias for the PAI-1 4G/5G polymorphism under two genetic models i.e., heterozygote (4G4G4 vs 
Table 2. Summary risk estimates for association of ACE I/D polymorphism with RPL in Iranian women

\begin{tabular}{|c|c|c|c|c|c|c|c|c|c|c|}
\hline \multirow{2}{*}{ Subgroup } & \multirow{2}{*}{ Genetic model } & \multirow{2}{*}{ Type of model } & \multicolumn{2}{|c|}{ Heterogeneity } & \multicolumn{4}{|c|}{ Odds ratio (OR) } & \multicolumn{2}{|c|}{$\begin{array}{l}\text { Publication } \\
\text { bias }\end{array}$} \\
\hline & & & $\mathrm{I}^{2}(\%)$ & $P_{H}$ & OR & $95 \%$ CI & $\mathrm{z}_{\mathrm{OR}}$ & $\mathrm{P}_{\mathrm{OR}}$ & $P_{\text {Beggs }}$ & $\mathbf{P}_{\text {Eggers }}$ \\
\hline \multirow[t]{5}{*}{ Overall } & D vs I & Fixed & 6.65 & 0.379 & 0.744 & $0.640-0.864$ & -3.863 & $\leq 0.001$ & 0.386 & 0.857 \\
\hline & DI vs II & Fixed & 0.00 & 0.472 & 0.872 & $0.657-1.157$ & -0.952 & 0.341 & 0.710 & 0.778 \\
\hline & DD vs II & Random & 52.55 & 0.039 & 0.941 & $0.595-1.487$ & -0.260 & 0.795 & 0.901 & 0.947 \\
\hline & $\mathrm{DD}+\mathrm{DI}$ vs II & Fixed & 13.69 & 0.323 & 0.774 & $0.601-0.996$ & -1.988 & 0.047 & 0.710 & 0.368 \\
\hline & DD vs DI+II & Fixed & 45.76 & 0.074 & 0.767 & $0.611-0.963$ & -2.285 & 0.022 & 0.265 & 0.458 \\
\hline \multicolumn{11}{|l|}{ RM NO. } \\
\hline \multirow[t]{5}{*}{$\geq 2$} & D vs I & Fixed & 27.81 & 0.245 & 0.666 & $0.539-0.822$ & -3.790 & $\leq 0.001$ & 0.734 & 0.211 \\
\hline & DI vs II & Fixed & 28.12 & 0.243 & 0.753 & $0.499-1.136$ & -1.1351 & 0.177 & 0.089 & 0.209 \\
\hline & DD vs II & Fixed & 59.04 & 0.062 & 0.781 & $0.494-1.233$ & -1.061 & 0.289 & 0.734 & 0.520 \\
\hline & $\mathrm{DD}+\mathrm{DI}$ vs II & Fixed & 22.68 & 0.275 & 0.754 & $0.516-1.101$ & -1.461 & 0.144 & 0.734 & 0.154 \\
\hline & DD vs DI+II & Random & 72.38 & 0.012 & 0.827 & $0.446-1.535$ & -0.601 & 0.548 & 0.089 & 0.237 \\
\hline \multirow[t]{5}{*}{$\geq 3$} & D vs I & Fixed & 0.00 & 0.613 & 0.838 & $0.676-1.039$ & -1.611 & 0.107 & 0.296 & 0.055 \\
\hline & DI vs II & Fixed & 0.00 & 0.560 & 0.975 & $0.657-1.448$ & -0.124 & 0.901 & 0.296 & 0.231 \\
\hline & DD vs II & Fixed & 10.49 & 0.327 & 0.790 & $0.513-1.217$ & -1.070 & 0.285 & 1.000 & 0.186 \\
\hline & $\mathrm{DD}+\mathrm{DI}$ vs II & Fixed & 0.00 & 0.461 & 0.896 & $0.618-1.300$ & -0.576 & 0.565 & 0.296 & $\leq 0.001$ \\
\hline & DD vs DI+II & Fixed & 0.00 & 0.399 & 0.796 & $0.572-1.108$ & -1.354 & 0.176 & 1.000 & 0.414 \\
\hline \multicolumn{11}{|c|}{ Genotyping methods } \\
\hline \multirow[t]{5}{*}{ ARMS-PCR } & D vs I & Fixed & 13.73 & 0.324 & 0.799 & $0.659-0.967$ & -2.298 & 0.022 & 0.734 & 0.441 \\
\hline & DI vs II & Fixed & 15.59 & 0.314 & 0.831 & $0.590-1.172$ & -1.054 & 0.292 & 0.734 & 0.781 \\
\hline & DD vs II & Fixed & 22.51 & 0.276 & 0.693 & $0.474-1.011$ & -1.903 & 0.057 & 0.734 & 0.179 \\
\hline & DD+DI vs II & Fixed & 0.00 & 0.605 & 0.761 & $0.554-1.047$ & -1.680 & 0.093 & 0.734 & 0.414 \\
\hline & DD vs DI+II & Fixed & 55.14 & 0.083 & 0.734 & $0.544-0.989$ & -2.030 & 0.042 & 0.308 & 0.288 \\
\hline \multirow[t]{5}{*}{ PCR-RFLP } & D vs I & Fixed & 23.37 & 0.271 & 0.667 & $0.524-0.850$ & -3.275 & 0.001 & 1.000 & 0.625 \\
\hline & DI vs II & Fixed & 17.81 & 0.296 & 0.932 & $0.560-1.551$ & -0.272 & 0.786 & 0.296 & 0.115 \\
\hline & DD vs II & Fixed & 53.67 & 0.115 & 1.039 & $0.591-1.827$ & 0.134 & 0.893 & 0.296 & 0.130 \\
\hline & $\mathrm{DD}+\mathrm{DI}$ vs II & Fixed & 37.97 & 0.199 & 0.985 & $0.609-1.590$ & -0.064 & 0.949 & 0.296 & 0.120 \\
\hline & DD vs DI+II & Fixed & 65.79 & 0.054 & 0.824 & $0.578-1.176$ & -1.067 & 0.286 & 1.000 & 0.555 \\
\hline
\end{tabular}

RM: Recurrent miscarriage, ARMS: Amplification-refractory mutation system, RFLP: Restriction fragment length polymorphism

5G5G5: $P_{\text {Beggs }}=0.060$ and $P_{\text {Eggers }}=0.021$ ) and recessive (4G4G4 vs 4G5G+5G5G5: $\mathrm{P}_{\text {Beggs }}=0.132$ and $\left.\mathrm{P}_{\text {Eggers }}=0.028\right)$. One probable explanation is that the results were underpowered and biased by limited sample sizes. Therefore, the Duval and Tweedie non-parametric "trim and fill" method was applied to adjust for publication bias on the PAI-1 4G/5G polymorphism under the heterozygote and recessive models. However, the results with and without "trim and fill" did not draw different results, indicating that the current meta-analysis results are statistically robust and reliable.

\section{Discussion}

The etiology of RPL is complicated, and several risk factors are involved in the development of the disease. In addition to fetal and maternal factors, including chromosomal abnormalities, endocrine and metabolic aberrations, and autoimmune abnormalities, genetic single nucleotide polymorphisms at different loci, also play essential roles in $\mathrm{RPL}^{(6,12,39)}$. In this metaanalysis, we evaluated the association of the ACE I/D and PAI-1 4G/5G polymorphisms with RPL risk in Iranian women from all eligible case-control studies. 
A

\begin{tabular}{|c|c|c|c|c|c|c|c|c|c|}
\hline \multirow[t]{2}{*}{$\underline{\text { Study name }}$} & \multicolumn{6}{|c|}{ Statistics for each study } & \multicolumn{3}{|l|}{ Odds ratio and $95 \% \mathrm{Cl}$} \\
\hline & $\begin{array}{l}\text { Odds } \\
\text { ratio }\end{array}$ & $\begin{array}{l}\text { Lower } \\
\text { limit }\end{array}$ & $\begin{array}{l}\text { Upper } \\
\text { limit }\end{array}$ & Z-Value & p-Value & & & & $\begin{array}{r}\text { Relative } \\
\text { weight }\end{array}$ \\
\hline Ghoraei 2007 & 0.611 & 0.417 & 0.896 & $2.526-$ & 0.012 & & & & 15.42 \\
\hline Bagheri 2010 & 1.020 & 0.597 & 1.742 & 0.072 & 0.942 & & & & 7.85 \\
\hline Arabi 2011 & 0.909 & 0.579 & 1.427 & $0.415-$ & 0.678 & & & & 11.05 \\
\hline Zonouzi 2013 & 1.053 & 0.641 & 1.728 & 0.204 & 0.839 & & & & 9.17 \\
\hline Shahkarami 2015 & 0.561 & 0.364 & 0.867 & $2.605-$ & 0.009 & & $\square$ & & 11.93 \\
\hline Fazelnia 2016 & 0.627 & 0.422 & 0.933 & $2.305-$ & 0.021 & & & & 14.32 \\
\hline Heidari 2017 & 0.772 & 0.587 & 1.016 & $1.844-$ & 0.065 & & & & 29.88 \\
\hline \multirow[t]{3}{*}{ Maziri 2017} & 0.495 & 0.044 & 5.548 & 0.570 & 0.568 & & & & 0.39 \\
\hline & 0.744 & 0.640 & 0.864 & $3.863-$ & 0.000 & & 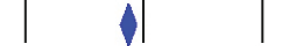 & & \\
\hline & & & & & & 0.01 & 0.1 & 100 & \\
\hline
\end{tabular}

B

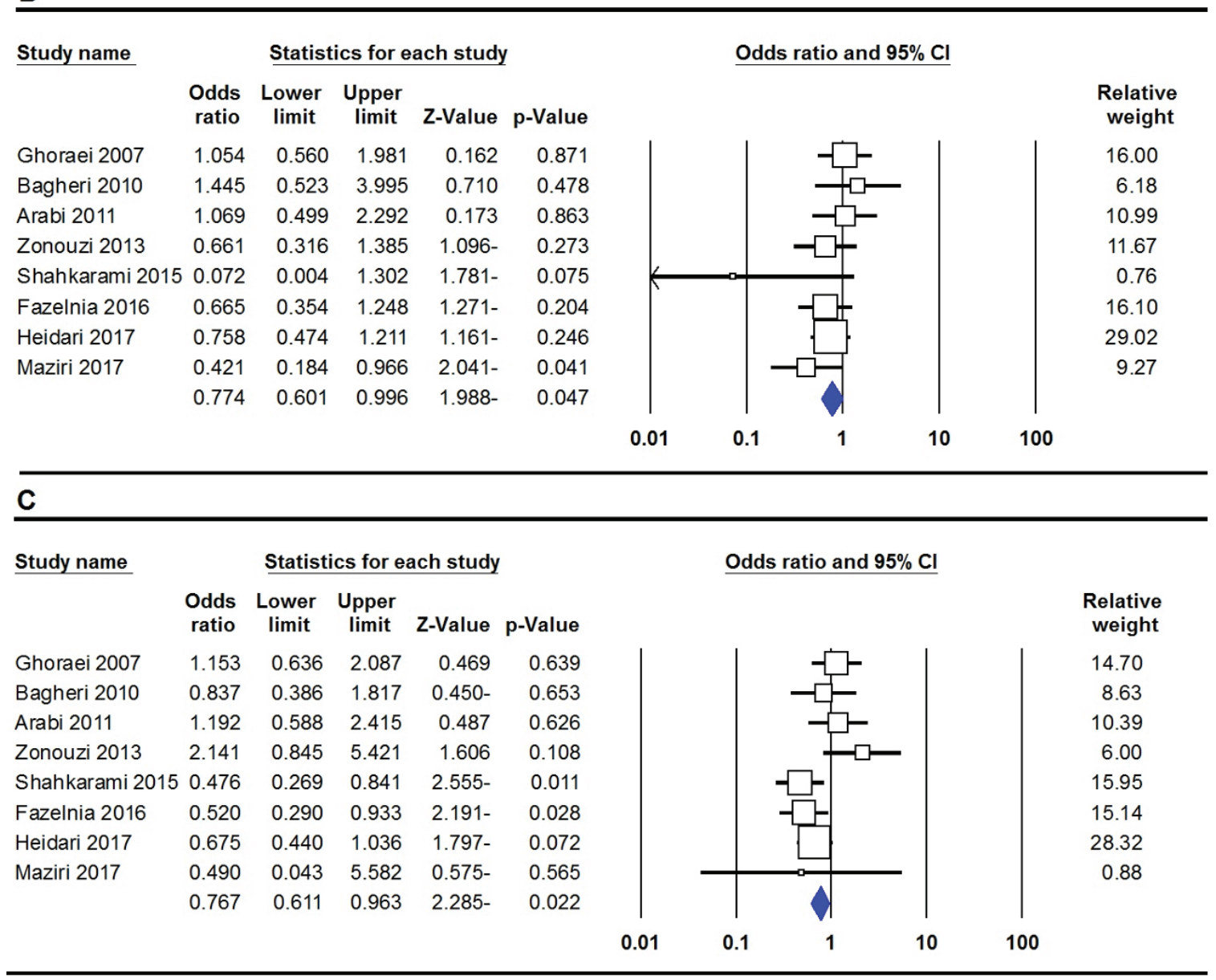

Figure 2. Forest plots for the association of ACE I/D polymorphism with risk of RPL risk in Iranian women. A: allele model; B: dominant model; and C: recessive model

The $4 \mathrm{G} / 5 \mathrm{G}$ polymorphism is a major genetic variant determinant of plasma PAI-1 levels. The $4 G$ allele has been reported to increase the risk for different diseases such as atherosclerosis and coronary artery disease ${ }^{(40)}$. On the other hand, the $5 \mathrm{G}$ allele may increase the risk of conditions such as abdominal aortic aneurysm. In this meta-analysis, our combined data based on six studies with 1,155 patients and 699 healthy subjects revealed that the PAI-1 4G/5G polymorphism was associated with an increased risk of RPL in Iranian women. In 2003, Wolf et al. ${ }^{(41)}$ first reported an increased risk of RPL in Austrian women in association with the PAI-1 4G/5G polymorphism. However, later studies in different ethnicities yielded controversial results ${ }^{(18,34,42,43)}$. In 2018, Adler et al. ${ }^{(44)}$ evaluated the associations of the -675 I/D and $4 G / 5 G$ polymorphisms 

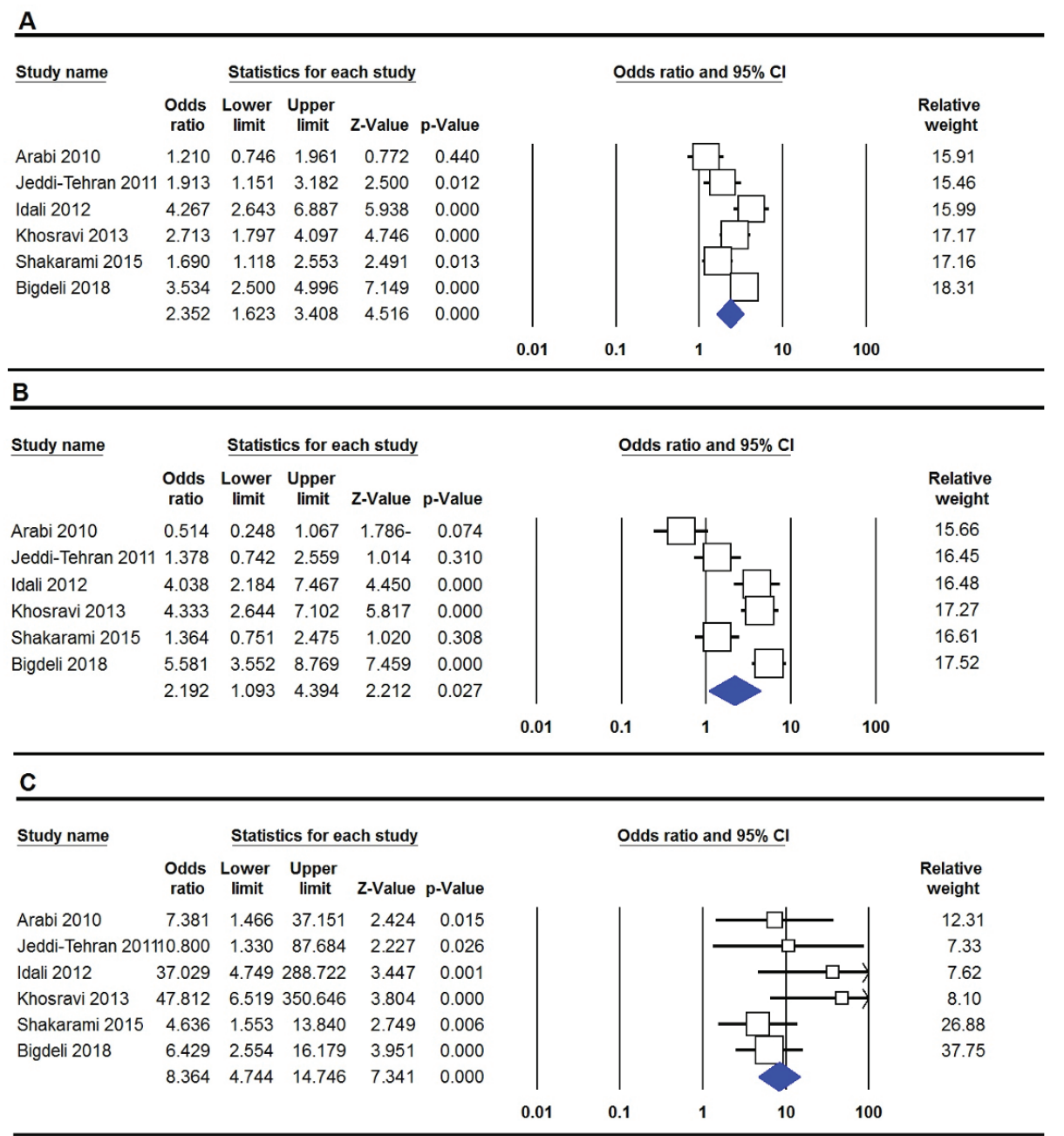

\begin{tabular}{|c|c|c|c|c|c|c|c|c|c|}
\hline \multirow[t]{2}{*}{ Study name } & \multicolumn{5}{|c|}{ Statistics for each study } & & \multicolumn{3}{|l|}{ Odds ratio and $95 \% \mathrm{Cl}$} \\
\hline & $\begin{array}{l}\text { Odds } \\
\text { ratio }\end{array}$ & $\begin{array}{l}\text { Lower } \\
\text { limit }\end{array}$ & $\begin{array}{c}\text { Upper } \\
\text { limit }\end{array}$ & Z-Value & p-Value & & & & $\begin{array}{r}\text { Relative } \\
\text { weight }\end{array}$ \\
\hline Arabi 2010 & 0.716 & 0.358 & 1.432 & $0.944-$ & 0.345 & & 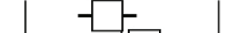 & | & 15.44 \\
\hline Jeddi-Tehran 2011 & 1.714 & 0.948 & 3.099 & 1.784 & 0.074 & & & & 16.38 \\
\hline Idali 2012 & 5.216 & 2.876 & 9.460 & 5.438 & 0.000 & & $\mathrm{H}$ & & 16.36 \\
\hline Khosravi 2013 & 2.495 & 1.567 & 3.972 & 3.852 & 0.000 & & & & 17.50 \\
\hline Shakarami 2015 & 1.661 & 0.936 & 2.948 & 1.734 & 0.083 & & & & 16.56 \\
\hline \multirow[t]{3}{*}{ Bigdeli 2018} & 5.571 & 3.616 & 8.584 & 7.788 & 0.000 & & & & 17.77 \\
\hline & 2.354 & 1.309 & 4.235 & 2.858 & 0.004 & & & | & \\
\hline & & & & & & 0.01 & 0.1 & 100 & \\
\hline
\end{tabular}

\section{$\underline{E}$}

\begin{tabular}{lrrrrrr} 
Study name & \multicolumn{5}{c}{ Statistics for each study } \\
\cline { 3 - 6 } & $\begin{array}{r}\text { Odds } \\
\text { ratio }\end{array}$ & $\begin{array}{c}\text { Lower } \\
\text { limit }\end{array}$ & $\begin{array}{c}\text { Upper } \\
\text { limit }\end{array}$ & Z-Value & p-Value \\
Arabi 2010 & 11.023 & 2.318 & 52.425 & 3.016 & 0.003 \\
Jeddi-Tehran 20119.791 & 1.217 & 78.806 & 2.144 & 0.032 \\
Idali 2012 & 20.250 & 2.649 & 154.810 & 2.899 & 0.004 \\
Khosravi 2013 & 16.500 & 2.271 & 119.885 & 2.771 & 0.006 \\
Shakarami 2015 & 3.892 & 1.376 & 11.007 & 2.562 & 0.010 \\
Bigdeli 2018 & 2.727 & 1.113 & 6.682 & 2.194 & 0.028 \\
& 5.920 & 3.035 & 11.547 & 5.217 & 0.000
\end{tabular}

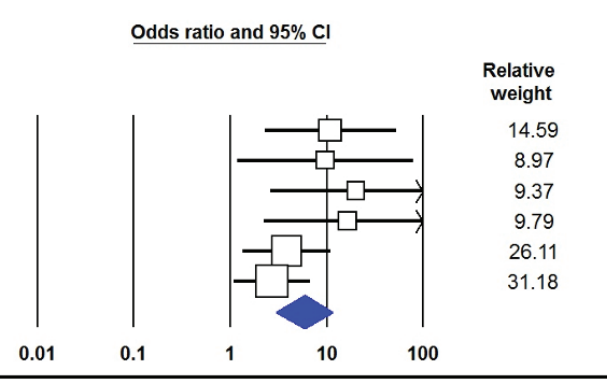

Figure 3. Forest plots for the association of PAI-1 4G/5G polymorphism with risk of RPL risk in Iranian women. A: allele model; B: heterozygote model; C: homozygote model; D: dominant model; and C: recessive model 

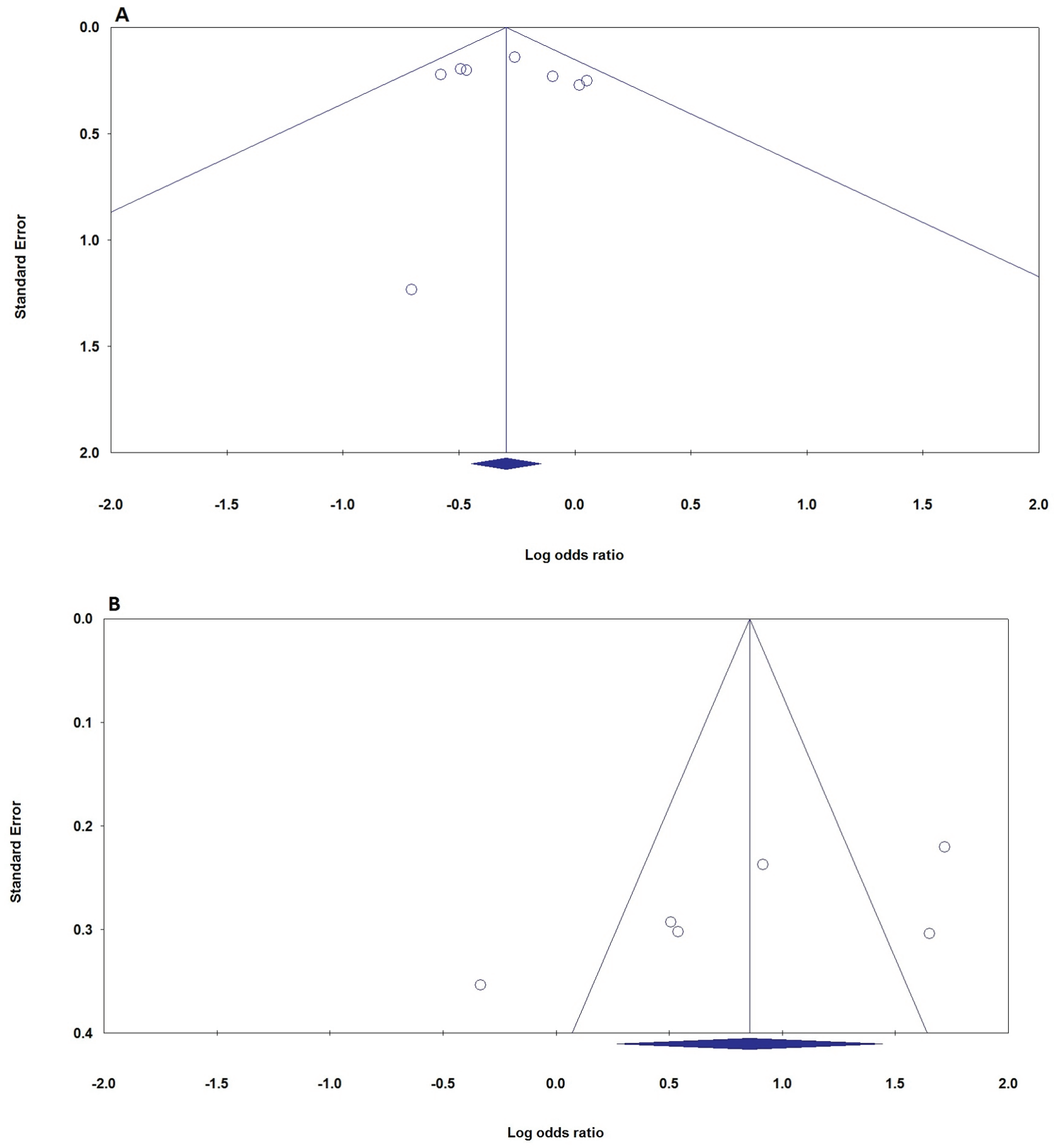

Figure 4. Begg's funnel plot of publication bias test for association of ACE I/D and PAI-1 4G/5G polymorphisms with risk of RPL risk in Iranian women. A: ACE (allele model); B: PAI-1 4G/5G (dominant model)

and PAI-1 with susceptibility to pregnancy loss in European and worldwide populations. Their pooled data revealed that there was no significant relationship between the 4G/5G polymorphism and pregnancy loss both in Europe or elsewhere in the world. However, Huang et al. ${ }^{(12)}$, in a meta-analysis based on 31 studies with 5617 patients and 3.952 healthy subjects reported that that the PAI-1 4G/5G polymorphism might contribute to the susceptibility of RPL; their subgroup analysis by ethnicity indicated a significantly elevated risk of RPL in Asians, Caucasians, and Africans. In 2015, Liu et al. ${ }^{(45)}$, in a meta-analysis of 22 studies with 4306 patients and 3076 controls, showed that the PAI-1 4G/5G polymorphism might be associated with RPL in the overall population $[\mathrm{OR}=1.89$; 95\% CI: (1.34-2.67); p<0.001]. In a subgroup analysis, they found that the PAI-1 4G/5G polymorphism was significantly associated with an increased risk of RPL in Caucasian 
Table 3. Summary risk estimates for association of PAI-1 4G/5G polymorphism with RPL in Iranian women

\begin{tabular}{|c|c|c|c|c|c|c|c|c|c|c|}
\hline \multirow{2}{*}{ Subgroup } & \multirow{2}{*}{ Genetic model } & \multirow{2}{*}{$\begin{array}{l}\text { Type of } \\
\text { model }\end{array}$} & \multicolumn{2}{|c|}{ Heterogeneity } & \multicolumn{4}{|c|}{ Odds ratio (OR) } & \multicolumn{2}{|c|}{$\begin{array}{l}\text { Publication } \\
\text { bias }\end{array}$} \\
\hline & & & $\mathrm{I}^{2}(\%)$ & $P_{H}$ & OR & $95 \% \mathrm{CI}$ & $\mathrm{Z}_{\mathrm{OR}}$ & $P_{\mathrm{OR}}$ & $P_{\text {Beggs }}$ & $P_{\text {Eggers }}$ \\
\hline \multirow[t]{5}{*}{ Overall } & $4 \mathrm{G} 4 \mathrm{G}$ vs $5 \mathrm{G} 5 \mathrm{G}$ & Random & 77.18 & 0.001 & 2.352 & $1.623-3.408$ & 4.516 & $\leq 0.001$ & 0.452 & 0.379 \\
\hline & $4 \mathrm{G} 5 \mathrm{G}$ vs $5 \mathrm{G} 5 \mathrm{G}$ & Random & 88.76 & $\leq 0.001$ & 2.192 & $1.093-4.394$ & 2.212 & 0.027 & 0.060 & 0.021 \\
\hline & 4G4G vs $5 \mathrm{G} 5 \mathrm{G}$ & Fixed & 22.68 & 0.263 & 8.364 & $4.744-14.756$ & 7.341 & $\leq 0.001$ & 0.259 & 0.061 \\
\hline & $4 \mathrm{G} 4 \mathrm{G}+4 \mathrm{G} 5 \mathrm{G}$ vs $5 \mathrm{G} 5 \mathrm{G}$ & Random & 85.59 & $\leq 0.001$ & 2.354 & $1.309-4.235$ & 2.858 & 0.004 & 0.259 & 0.120 \\
\hline & $4 G 4 G$ vs $4 G 5 G+5 G 5 G$ & Random & 23.72 & 0.256 & 5.208 & $3.005-9.025$ & 5.882 & $\leq 0.001$ & 0.132 & 0.028 \\
\hline \multicolumn{11}{|l|}{ RM no } \\
\hline \multirow[t]{5}{*}{$\geq 2$} & $4 G 4 G$ vs $5 G 5 G$ & Fixed & 25.21 & 0.263 & 2.083 & $1.617-2.682$ & 5.684 & $\leq 0.001$ & 1.000 & 0.848 \\
\hline & $4 \mathrm{G} 5 \mathrm{G}$ vs $5 \mathrm{G} 5 \mathrm{G}$ & Random & 83.16 & 0.003 & 2.046 & $0.920-4.551$ & 1.756 & 0.079 & 1.000 & 0.102 \\
\hline & $4 \mathrm{G} 4 \mathrm{G}$ vs $5 \mathrm{G} 5 \mathrm{G}$ & Fixed & 51.41 & 0.128 & 8.390 & $3.509-20.061$ & 4.783 & $\leq 0.001$ & 1.000 & 0.374 \\
\hline & $4 \mathrm{G} 4 \mathrm{G}+4 \mathrm{G} 5 \mathrm{G}$ vs $5 \mathrm{G} 5 \mathrm{G}$ & Fixed & 0.00 & 0.465 & 2.003 & $1.472-2.727$ & 4.416 & $\leq 0.001$ & 1.000 & 0.114 \\
\hline & $4 G 4 G$ vs $4 G 5 G+5 G 5 G$ & Fixed & 0.00 & 0.392 & 5.871 & $2.528-13.631$ & 4.118 & $\leq 0.001$ & 1.000 & 0.207 \\
\hline \multirow[t]{5}{*}{$\geq 3$} & $4 G 4 G$ vs $5 G 5 G$ & Random & 87.73 & $\leq 0.001$ & 2.653 & $1.299-5.418$ & 2.678 & 0.007 & 1.000 & 0.698 \\
\hline & $4 G 5 G$ vs $5 G 5 G$ & Random & 93.44 & $\leq 0.001$ & 2.318 & $0.613-8.774$ & 1.238 & 0.216 & 0.296 & 0.329 \\
\hline & $4 \mathrm{G} 4 \mathrm{G}$ vs $5 \mathrm{G} 5 \mathrm{G}$ & Fixed & 14.93 & 0.309 & 8.345 & $3.955-17.606$ & 5.570 & $\leq 0.001$ & 0.296 & 0.389 \\
\hline & $4 \mathrm{G} 4 \mathrm{G}+4 \mathrm{G} 5 \mathrm{G}$ vs $5 \mathrm{G} 5 \mathrm{G}$ & Random & 92.39 & $\leq 0.001$ & 2.814 & $0.860-9.202$ & 1.711 & 0.087 & 0.296 & 0.423 \\
\hline & $4 \mathrm{G} 4 \mathrm{G}$ vs $4 \mathrm{G} 5 \mathrm{G}+5 \mathrm{G} 5 \mathrm{G}$ & Random & 55.99 & 0.103 & 4.764 & $2.305-9.845$ & 4.215 & $\leq 0.001$ & 0.296 & 0.067 \\
\hline
\end{tabular}

RM: Recurrent miscarriage

populations [OR=2.23; 95\% CI: (1.44-3.46); $\mathrm{p}<0.001]$, but they reported that the PAI-1 4G/5G polymorphism was not significantly associated with RPL risk in Asian populations ${ }^{(45)}$.

The current meta-analysis results showed that ACE I/D polymorphism was associated with increased risk of RPL in Iranian women under the allele genetic model [D vs I: $\mathrm{OR}=0.745$, 95\% CI: (0.641-0.866); p $\leq 0.001]$. Recently, Gumus ${ }^{(46)}$ in a case-control study, showed that the ACE I/D polymorphism was associated with idiopathic recurrent pregnancy loss (IRPL), and women with DD or ID genotypes had a $72 \%$ higher risk of developing IRPL than women with the II genotype. In 2018, Aslebahar et al. ${ }^{(39)}$, in a meta-analysis of 26 case-control studies with 3140 patients with RPL and 3.370 controls, showed that that ACE I/D polymorphism was associated with increased risk of RPL in the overall population. Similarly, Wang et al. ${ }^{(47)}$, in a meta-analysis on 11 studies with a total of 3.357 individuals showed that the polymorphism was linked with an increased risk of recurrent miscarriage. By contrast, Pereza et al. ${ }^{(48)}$, in a meta-analysis based on 1,192 patients and 736 healthy subjects, showed no association between the ACE I/D polymorphism and RPL. Moreover, they performed a case-control study on 149 women (with $\geq 3$ spontaneous abortions) and 149 healthy subjects to evaluate the association among Croatian women. Similarly, they showed a negative association between the ACE I/D polymorphism and the risk of RPL ${ }^{(48)}$. In 2013, Su et al. ${ }^{(49)}$, in a meta-analysis based on 11 studies, reported a significant association between the ACE I/D polymorphism and IRPL. However, they found no significant association between the ACE I/D polymorphism and IRPL in Caucasian and nonCaucasian patients ${ }^{(49)}$.

To our knowledge, this is the first meta-analysis to prove a significant association of the ACE I/D and PAI-1 4G/5G polymorphisms with RPL risk in Iranian women. However, the results presented here should be interpreted with caution because of several potential limitations. First, only published studies were included in this meta-analysis and some unpublished studies may have been missed, which may have biased the observed associations of ACE I/D and PAI-1 4G/5G polymorphisms with RPL in Iranian women. Second, there was relatively high heterogeneity under some genetic models. Third, the number of studies and the sample sizes were relatively small for analysis, thereby having insufficient power to estimate the association of ACE I/D and PAI-1 4G/5G polymorphisms with RPL in Iranian women. Fourth, the pooled estimates were based on unadjusted data, which might have affected the accuracy of the results. This is a meta-analysis with insufficient individual data to stratify results by other risk factors such as maternal age, environmental pollution, smoking; therefore, the association in these factors could not be assessed. Finally, RPL is a multifactorial disease influenced by many compound factors, including single or combined genetic polymorphisms and environmental factors. However, the impact of gene-gene, 
gene-environment interactions and also ACE I/D and PAI-1 $4 \mathrm{G} / 5 \mathrm{G}$ polymorphisms interactions were precluded owing to insufficient original data.

\section{Conclusion}

Considering all the results, the pooled data indicated that ACE I/D and PAI-1 4G/5G polymorphisms were associated with an increased risk of RPL in Iranian women. Moreover, these polymorphisms were associated with RPL risk by the number of previous miscarriages. These significant findings suggest that investigation might be adequate for ACE I/D and PAI-1 4G/5G polymorphisms in association with RPL in Iranian women.

\section{Acknowledgement}

I would like to express my sincere gratitude to Professor Mohammad Hasan Sheikhha for his motivation, knowledge and support during this research.

\section{Ethics}

Peer-review: Internally peer-reviewed.

\section{Authorship Contributions}

Surgical and Medical Practices: S.A.D., M.K.Z., R.S.T., A.J., M.N., S.R.M., H.N., Concept: R.B., Design: S.A.D., M.K.Z., R.S.T., A.J., M.N., S.R.M., H.N., Data Collection or Processing: S.A.D., H.N., Analysis or Interpretation: S.A.D., M.K.Z., R.S.T., A.J., M.N., S.R.M., H.N., Literature Search: S.A.D., M.K.Z., R.S.T., A.J., M.N., S.R.M., H.N., Writing: S.A.D., M.K.Z., R.S.T., A.J., M.N., S.R.M., H.N.

Conflict of Interest: No conflict of interest was declared by the authors.

Financial Disclosure: The authors declared that this study received no financial support.

\section{References}

1. Aslbahar F, Neamatzadeh H, Tabatabaiee R, Karimi-Zarchi M, Javaheri A, Mazaheri M, et al. Association of angiotensin-converting enzyme insertion/deletion polymorphism with recurrent pregnancy loss: a meta-analysis of 26 case-control studies. Rev Bras Ginecol Obstet 2018;40:631-41.

2. Maziri P, Tehrani GA, Hidagi FB, Nejatollahi M, Asadi S. Association between thrombophilic gene polymorphisms and recurrent pregnancy loss in iranian women. Iranian Journal of Neonatology 2017;8:13-9.

3. Kamali M, Hantoushzadeh S, Borna S, Neamatzadeh H, Mazaheri M, Noori-Shadkam M, et al. Association between thrombophilic genes polymorphisms and recurrent pregnancy loss susceptibility in Iranian women: A systematic review and meta-analysis. Iran Biomed J 2018;22:78-89.

4. Behforouz A, Dastgheib SA, Abbasi H, Karimi-Zarchi M, Javaheri A, Hadadan A, et al. Association of MMP-2, MMP-3, and MMP-9 polymorphisms with susceptibility to recurrent pregnancy loss. Fetal Pediatr Pathol 2020:1-9.

5. Soleimani-Jadidi S, Abbasi H, Javaheri A, Behforouz A, Zanbagh L, Meibodi B, et al. Cumulative evidence for association of il-10 -1082g $>$ a polymorphism with susceptibility to recurrent pregnancy loss: a systematic review and meta-analysis. Fetal Pediatr Pathol 2020:1-15.
6. Heidari MM, Sheikholeslami M, Yavari M, Khatami M, Seyedhassani $\mathrm{SM}$. The association of renin-angiotensinogen system genes polymorphisms and idiopathic recurrent pregnancy loss. Hum Fertil (Camb) 2017;22:164-70.

7. Neamatzadeh H, Ramazani V, Kalantar SM, Ebrahimi M, Sheikhha $\mathrm{MH}$. Serum immune reactivity against $\beta 2$-Glycoprotein-I and antineutrophil cytoplasmic auto-antibodies by ELI-P-Complex Screening Technology in recurrent miscarriage. Minerva Ginecol 2016;68:243-9.

8. Colucci G, Tsakiris DA. Thrombophilia screening revisited: an issue of personalized medicine. J Thromb Thrombolysis 2020;49:618-29.

9. Simcox LE, Ormesher L, Tower C, Greer IA. Thrombophilia and pregnancy complications. Int J Mol Sci 2015;16:28418-28. doi:10.3390/ijms161226104.

10. Ormesher L, Simcox L, Tower C, Greer IA. Management of inherited thrombophilia in pregnancy. Womens Health (Lond) 2016;12:433-41.

11. Nassour-Mokhtari I, Loukidi B, Moussouni A, Bettioui R, Benhabib R, Merzouk $\mathrm{H}$, et al. Inherited thrombophilia and recurrent pregnancy loss: a single-center case-control study in North-Western Algeria. Egyptian J Med Hum Genet 2020;21:1-7.

12. Huang Z, Tang W, Liang Z, Chen Q, Li M, Li Y, et al. Plasminogen activator inhibitor-1 polymorphism confers a genetic contribution to the risk of recurrent spontaneous abortion: an updated meta-analysis. Reprod Sci 2017;24:1551-60.

13. Vaiman D. Genetic regulation of recurrent spontaneous abortion in humans. Biomed J 2015;38:11-24.

14. Hemsworth EM, O'Reilly AM, Allen VM, Kuhle S, Brock JK, Knowledge Synthesis Group on Determinants of Preterm/LBW Births. Association between factor $\mathrm{v}$ leiden mutation, small for gestational age, and preterm birth: a systematic review and meta-analysis. J Obstet Gynaecol Can 2016;38:897-908.

15. Chatzidimitriou M, Chatzidimitriou D, Mavridou M, Anetakis C, Chatzopoulou F, Lialiaris T, et al. Thrombophilic gene polymorphisms and recurrent pregnancy loss in Greek women. Int J Lab Hematol 2017;39:590-5

16. Shi X, Xie X, Jia Y, Li S. Maternal genetic polymorphisms and unexplained recurrent miscarriage: a systematic review and metaanalysis. Clin Genet 2017;91:265-84.

17. Walker ID. Thrombophilia in pregnancy. J Clin Pathol 2000;53:57380 .

18. Shakarami F, Akbari MT, Zare Karizi S. Association of plasminogen activator inhibitor-1 and angiotensin converting enzyme polymorphisms with recurrent pregnancy loss in Iranian women. Iran J Reprod Med 2015;13:627-32.

19. Ranellou K, Paraskeva A, Kyriazopoulos P, Batistatou A, Evangelou A, El-Aly M, et al. Polymorphisms in prothrombotic genes in young stroke patients in Greece: a case-controlled study. Blood Coagul Fibrinolysis 2015;26:430-5.

20. Li Y, Liu F-X, Yuan C, Meng L. Association between plasminogen activator inhibitor gene polymorphisms and osteonecrosis of the femoral head susceptibility. Medicine (Baltimore) 2017;96:e7047. doi:10.1097/MD.0000000000007047.

21. Sobhan MR, Mahdinezhad-Yazdi M, Moghimi M, Aghili K, Jafari M, Zare-Shehneh M, et al. Plasminogen activator inhibitor- 1 4g/5g polymorphism contributes to osteonecrosis of the femoral head susceptibility: evidence from a systematic review and meta-analysis. Arch Bone Jt Surg 2018;6:468-77.

22. Dastgheib SA, Najafi F, Shajari A, Bahrami R, Asadian F, Sadeghizadeh-Yazdi J, et al. Association of plasminogen activator inhibitor-1 4G5G polymorphism with risk of diabetic nephropathy and retinopathy: a systematic review and meta-analysis. J Diabetes Metab Disord 2020;19:2005-16 
23. Jafari M, Jarahzadeh MH, Dastgheib SA, Seifi-Shalamzari N, RaeeEzzabadi A, Sadeghizadeh-Yazdi J, et al. Association of PAI-1 rs1799889 polymorphism with susceptibility to ischemic stroke: a huge meta-analysis based on 44 studies. Acta Medica (Hradec Kralove) 2020;63:31-42.

24. Nie $\mathrm{W}$, Li B, Xiu Q. The -675 4G/5G polymorphism in plasminogen activator inhibitor-1 gene is associated with risk of asthma: a meta-analysis. PLoS One. 2012;7:e34385. doi:10.1371/journal. pone.0034385.

25. Ye Y, Vattai A, Zhang X, Zhu J, Thaler CJ, Mahner S, et al. Role of plasminogen activator inhibitor type 1 in pathologies of female reproductive diseases. Int J Mol Sci 2017;18:1651.

26. Moghimi M, Kargar S, Jafari MA, Ahrar H, Jarahzadeh MH, Neamatzadeh $\mathrm{H}$, et al. Angiotensin converting enzyme insertion/ deletion polymorphism is associated with breast cancer risk: a metaanalysis. Asian Pac J Cancer Prev 2018;19:3225-31.

27. El Sharkawy RM, Zaki AM, El Fattah Kamel AA, Bedair RN Ahmed AS. Association between the polymorphisms of angiotensin converting enzyme (Peptidyl-Dipeptidase A) INDEL mutation (I/D) and Angiotensin II type I receptor (A1166C) and breast cancer among post menopausal Egyptian females. Alexandria J Med 2014;50:26774.

28. Sun M, Liu C, Wei F, Zhong J, Sun Y. Association of angiotensin I converting enzyme insertion/deletion polymorphism with breast cancer: a meta-analysis. J Renin Angiotensin Aldosterone Syst 2011;12:611-6.

29. Fazelnia S, Farazmandfar T, Hashemi-Soteh SMB. Significant correlation of angiotensin converting enzyme and glycoprotein IIIa genes polymorphisms with unexplained recurrent pregnancy loss in north of Iran. Int J Reprod Biomed 2016;14:323-8.

30. Azin SA, Golbabaei F, Warmelink JC, Eghtedari S, Haghani S, Ranjbar F. Association of depression with sexual function in women with history of recurrent pregnancy loss: descriptive-correlational study in Tehran, Iran. Fertil Res Pract 2020;6:21.

31. Bigdeli R, Younesi MR, Panahnejad E, Asgary V, Heidarzadeh $\mathrm{S}$, Mazaheri $\mathrm{H}$, et al. Association between thrombophilia gene polymorphisms and recurrent pregnancy loss risk in Iranian women. Syst Biol Reprod Med 2018;64:274-82.

32. Soltanghoraee H, Memariani T, Aarabi M, Hantoushzadeh S, Arefi S, Aarabi M, et al. Association of ACE, PAI-1 and coagulation factor XIII gene polymorphisms with recurrent spontaneous abortion in Iranian patients. J Reprod Infertil 2007;7:324-30.

33. Bagheri M, Abdi Rad I, Omrani MD, Nanbaksh F. Polymorphisms of the angiotensin converting enzyme gene in Iranian Azeri Turkish women with unexplained recurrent pregnancy loss. Hum Fertil (Camb) 2010;13:79-82.

34. Aarabi M, Memariani T, Arefi S, Aarabi M, Zadeh SH, Akhondi MA, et al. Polymorphisms of plasminogen activator inhibitor-1, angiotensin converting enzyme and coagulation factor XIII genes in patients with recurrent spontaneous abortion. J Matern Fetal Neonatal Med 2011;24:545-8

35. Poursadegh Zonouzi A, Chaparzadeh N, Ghorbian S, Sadaghiani MM, Farzadi L, Ghasemzadeh A, et al. The association between thrombophilic gene mutations and recurrent pregnancy loss. J Assist Reprod Genet 2013;30:1353-9.

36. Jeddi-Tehrani M, Torabi R, Zarnani AH, Mohammadzadeh A, Arefi S, Zeraati $\mathrm{H}$, et al. Analysis of plasminogen activator inhibitor-1, integrin beta3, beta fibrinogen, and methylenetetrahydrofolate reductase polymorphisms in iranian women with recurrent pregnancy loss. Am J Reprod Immunol 2011;66:149-56.

37. Idali F, Zareii S, Mohammad-Zadeh A, Reihany-Sabet F, AkbarzadehPasha Z, Khorram-Khorshi H-R, et al. Plasminogen activator inhibitor 1 and methylenetetrahydrofolate reductase gene mutations in iranian women with polycystic ovary syndrome. Am J Reprod Immunol 2012;68:400-7.

38. Khosravi F, Zarei S, Ahmadvand N, Akbarzadeh-Pasha Z, Savadi E, Zarnani A-H, et al. Association between plasminogen activator inhibitor 1 gene mutation and different subgroups of recurrent miscarriage and implantation failure. J Assist Reprod Genet 2014;31:121-4.

39. Aslebahar F, Neamatzadeh H, Meibodi B, Karimi-Zarchi M, Tabatabaei RS, Noori-Shadkam M, et al. Association of Tumor Necrosis Factor- $\alpha$ (TNF- $\alpha$ ) -308G>A and -238G>A Polymorphisms with Recurrent Pregnancy Loss Risk: A Meta-Analysis. Int J Fertil Steril 2019;12:28492.

40. Margaglione M, Cappucci G, Colaizzo D, Giuliani N, Vecchione G, Grandone E, et al. The PAI-1 gene locus $4 \mathrm{~g} / 5 \mathrm{G}$ polymorphism is associated with a family history of coronary artery disease. Arterioscler Thromb Vasc Biol 1998;18:152-6.

41. Wolf CE, Haubelt H, Pauer HU, Hinney B, Krome-Cesar C, Legler TJ, et al. Recurrent pregnancy loss and its relation to FV Leiden, FII G20210A and polymorphisms of plasminogen activator and plasminogen activator inhibitor. Pathophysiol Haemost Thromb 2003;33:134-7.

42. Al Sallout RJ, Sharif FA. Polymorphisms in NOS3, ACE and PAI-1 genes and risk of spontaneous recurrent miscarriage in the gaza strip. Med Princ Pract 2010;19:99-104.

43. Ozdemir O, Yenicesu GI, Silan F, Köksal B, Atik S, Ozen F,et al. Recurrent pregnancy loss and its relation to combined parental thrombophilic gene mutations. Genet Test Mol Biomarker 2012;16:279-86.

44. Adler G, Mahmutbegovic E, Valjevac A, Adler MA, Mahmutbegovic $\mathrm{N}$, Safranow K, et al. Association between - 675 ID, 4G/5G PAI-1 gene polymorphism and pregnancy loss: a systematic review. Acta Inform Med 2018;26:156-9.

45. Liu Y, Liu Y, Zhang R, Tan J, Chen L, Liu Y. Meta-analysis of the association between plasminogen activator inhibitor-1 4g/5g polymorphism and recurrent pregnancy loss. Med Sci Monit 2015;21:1051-6.

46. Gumus E. The powerful association of angiotensin-converting enzyme insertion/deletion polymorphism and idiopathic recurrent pregnancy loss. Ginekol Pol 2018;89:573-6.

47. Wang Z, Wang P, Wang X, He X, Wang Z, Xu D, et al. Significant association between angiotensin-converting enzyme gene insertion/ deletion polymorphism and risk of recurrent miscarriage: a systematic review and meta-analysis. Metabolism 2013;62:1227-38.

48. Pereza N, Ostojić S, Zdravčević M, Volk M, Kapović M, Peterlin B. Insertion/deletion polymorphism intron 16 of ACE gene in idiopathic recurrent spontaneous abortion: case-control study, systematic review and meta-analysis. Reprod Biomed Online 2016;32:237-46.

49. Su MT, Lin SH, Chen YC, Kuo PL. Genetic association studies of ACE and PAI-1 genes in women with recurrent pregnancy loss: a systematic review and meta-analysis. Thrombos Haemost 2013;109:8-15. 